\title{
Życie i historia relikwii świętego Spirydona biskupa Tremithus
}

\author{
Adam Magruk \\ Chrześcijańska Akademia Teologiczna w Warszawie \\ Polska \\ admagruk@wp.pl
}

\begin{abstract}
Adam Magruk, Life of saint Spiridon and history on relic to the bishop of Tremithus, Elpis, 17 2015: 81-85.
\end{abstract}
\begin{abstract}
In the last few years Saint Spyridon - the great hierarch of Greek Orthodox Church, is becoming increasingly known, glorified and praised by Orthodox Christians from all over the world including slavic territories. In Russia, for instance, St Spyridon is honored on a par with St Nikolaos the Wonderworker. Therefore, his biography is truly admirable, e.g. occurrences before the ordination to the priesthood and even more interestingly facts after he was made Bishop of Trimythous. St Spyridon participated in the sessions of the Firts Ecumenical Council, where he played a significant and remarkable role. Special attention deserve also the history of St Spyridon's relics, which repose on the Greek island of Corfu to this day as well as his miraculous right hand returned to Orthodox Greeks by Catholic Church after c. 800 years.
\end{abstract}

\begin{abstract}
Streszczenie: W ciągu ostatnich kilku lat postać świętego Spirydona - wielkiego hierarchy Cerkwi Greckiej - staje się coraz bardziej znana, czczona i wychwalana przez wiernych prawosławnych na całym świecie, w tym również na gruncie słowiańskim. W Rosji na ten przykład jest ona czczona niemal na równi ze świętym Mikołajem Cudotwórcą. Godnym podziwu jest więc jego życiorys: m.in. perypetie do przyjęcia święceń kapłańskich a jeszcze ciekawszy po chirotonii biskupiej. Na szczególną uwagę zasługuje jego czynny udział w Pierwszym Soborze Powszechnym oraz opis historii jego doczesnych szczątków - spoczywających do dnia dzisiejszego na greckiej wyspie Korfu - a także cudownej prawicy świętego, zwróconej dopiero po ok. 800 latach przez Kościół Katolicki prawosławnym Grekom.
\end{abstract}

Keywords: Saint Spyridon, bishop of Tremithus, First Council of Nicaea, heresy of Arius, relic, right hand of Saint Spyridon

Słowa kluczowe: Święty Spirydon, biskup Tremithus, Sobór w Nicei, herezja Ariusza, relikwie, prawa ręka Spirydona

\section{Wprowadzenie}

W ciągu ostatnich kilku lat postać świętego Spirydona - wielkiego hierarchy Cerkwi Greckiej - staje się coraz bardziej znana, czczona i wychwalana przez wiernych prawosławnych na całym świecie, $w$ tym również na gruncie słowiańskim. W Rosji na ten przykład jest ona czczona niemal na równi ze świętym Mikołajem Cudotwórcą. Nie wszyscy jednak, do końca wiedzą kim właściwie był ów biskup i czym zasłużył sobie na tak ogromne uznanie i uwielbienie Matki Cerkwi. Dlatego też warto przyjrzeć się z bliska jego osobie i spuściźnie duchowej jaką po sobie pozostawił.

\section{Biografia świętego Spirydona}

W poszukiwaniu źródeł, traktujących o żywocie świetego Spirydona należałoby w pierwszej kolejności odwołać się do dzieł znanych starożytnych historyków Kościoła takich jak Sokrates Scholastyk (IV w.), Sozomenos (V w.) czy bizantyjskiego teologa Gelazjusza z Cyzyku (V w.). Zaskakującym z pewnością jest fakt, iż pierwsza znana nam biografia Spirydona datowana jest dopiero na wiek VII. Najcenniejszy jednak tekst żywotu świętego został spisany na początku dziewiątego stulecia przez bizantyjskiego hagiografa Symeona Metaphrastesa, który z kolei do jego sporządzenia wykorzystał pracę autorstwa współczesnego Spirydonowi świętego Triphilliosa biskupa Nikozji, który był również jego uczniem, o czym zresztą informuje on czytelników w przedmowie swojej rozprawy.

Przyszły biskup Tremithus przyszedł na świat około 270 roku w biednej rodzinie, zamieszkującej niewielką cypryjską miejscowość Asia/Askija. Jego pobożni rodzice - a w późniejszym okresie i on sam - utrzymywali się z pasterstwa owiec. Tym, co charakteryzowało go od najmłodszych lat jego życia, to w głównej mierze łagodność starotestamentowego Dawida, serdeczna dobroć patriarchy Jakuba oraz Abrahamowa gościnność oraz miłość. Bezdomni zawsze mogli liczyć na schronienie w jego domu zaś wędrowcy odnajdowali w nim odpoczynek i pożywienie. Prostota i wielkoduszność, jaka biła z jego oblicza, pokora, skromność ale i miłość wobec bliźniego cechowały Spirydona, który nie miał względu na człowieka. Za nieustanną pamięć o Bogu natomiast, Pan obdarzył swego wiernego sługę darem przepowiadania przyszłości, uzdrawiania nieuleczalnych chorób i wyganiania biesów. Symeon Metapfrastes zauważa coś jeszcze, bardzo istotnego w jego sposobie bycia: Nie był osoba elokwentna ani elegancka $w$ swoim sposobie bycia, nie cieszyly go tlumy ani życie publiczne, lecz byt prosty i spokojny jak nikt inny.

Nie był on również osobą wykształconą jak na te czasy. Nie ukończył żadnych szkół, uczelni wyższych, jak miało 
to miejsce w przypadku innych znanych Wielkich Ojców i nauczycieli Kościoła.

Sozomenos podaje, iż Spirydon był żonaty. Nie dane mu jednak było długo cieszyć się radością płynącą z błogosławionego życia małżeńskiego. Jego żona umiera dosłownie kilka lat po ślubie, „osierocając” Spirydona i ich dzieci, chociaż z imienia znamy jedynie jedno z nich - córkę Irenę. Ogromnym oparciem w tych trudnych chwilach były dla niego słowa biblijnego Hioba Cierpiętnika: Bóg dał i Bóg zabrat. Niech będzie imię Pańskie błogosławione na wieki (Hi $1,21)$. Jedyne pocieszenie w tym ogromnym bólu i smutku święty odnajdywał w czytaniu i głoszeniu innym Słowa Bożego. To właśnie za Jego pośrednictwem pocieszał każdego, kto pogrążony był w rozpaczy i potrzebował słowa otuchy i to Ono stało się odtąd jego najwierniejszym towarzyszem życia. Wielu wówczas zaczęło odnajdywać u boku Spirydona spokój i wyciszenie w swoich codziennych troskach ale i orędownika w sytuacjach beznadziejnych.

Wartym zaakcentowania jest tutaj informacja, zawarta jedynie w lacińskim Synaksarionie, mówiąca o tym, że Spirydon wyznał wiarę w Chrystusa przed cesarzem Maksymianem, za co miał być zesłany na wygnanie, i co więcej, pozbawiony prawego oka. Oprócz tego, wspomina się tam również i o tym, że wraz z żoną i córką niósł on ciężar życia mniszego w palestyńskim monasterze na górze Karmel. Według wszelkiego prawdopodobieństwa jednak, tylko co przedstawiona wersja wydarzeń daleka jest od prawdy, bowiem nie potwierdzają jej żadne inne historyczne materiały źródłowe, o czym przekonuje wybitny grecki historyk i teo$\log$, ks. Georgios Metallinos.

$\mathrm{Z}$ całą pewnością natomiast, naukowcy zgodni są co do tego, iż Spirydon, po utracie ukochanej i licznych namowach, głównie ze strony hierarchii kościelnej, jak też gorącej prośbie wiernych, przyjmuje święcenia kapłańskie, stając się tym samym gorliwym sługą Ewangelii, wypełniwszy w sposób najbardziej doskonały słowa Apostoła Pawła, który wymagał od pasterza stada Chrystusowego nienaganności, trzeźwości umysłu, rozsądku, przyzwoitości, gościnności, sposobności do nauczania, niekłótliwości, opanowania i niepożądania bogactw ziemskich (1 Tym 3,2-4). Sokrates Scholastyk pisał o nim: Jeśli chodzi o Spirydona, byt to zwykły pastuch, który odznaczał się tak wielka pobożnościa, że uznano go za godnego kandydata na pasterza wiernych.

Po śmierci biskupa Tremithus (dziś jest to niewielkie miasteczko o nazwie Tremetusia, leżące ok. $25 \mathrm{~km}$ od centrum Nikozji), nikt nie miał wątpliwości, że jedynie Spirydon będzie najbardziej godnym objąć to wysokie i zaszczytne stanowisko. Wierni jednogłośnie wybrali swego nowego arcypasterza. Ta, nowa sytuacja nie zmieniła nic $\mathrm{w}$ jego zachowaniu. Nie pozwolił nigdy - a szczególnie teraz, kiedy jako hierarsze będą mu oddawać szczególną cześć i uznanie - aby pycha wkroczyła do jego serca. Sokrates nie omieszka w tym miejscu zaakcentować pewnego - być może małoistotnego ale jakże bardzo pouczającego momentu: Jednakże przy nadzwyczajnej swej skromności, piastując godność biskupa pasat nadal owce.

Niezwykła pokora i prostota towarzyszyły mu również po chirotonii biskupiej. Nadal nosił skromny ubiór, zaś jego głowę codziennie pokrywała czapka - wykonana ze splecionych gałęzi wierzbowych (lub liści palmowych bądź też z sierści owiec) - jaką nosili w ówczesnych czasach wiejscy chłopi i pasterze. Już na początku swej pracy duszpasterskiej Spirydon musiał stawić czoło suszy, połączonej z plagą dziesiątkującą mieszkańców Cypru. Widząc nieszczęście, jakie spadło na wiernych, Spirydon wzniósł swe modlitwy do Boga. Zdaniem Symeona Metathrastesa: Potrzeba wymagała kolejnego Eliasza lub kogoś do niego podobnego, kogoś kto swa modlitwa otworzy niebiosa. Nie było nikogo takiego poza Spirydonem. Gdy plaga szalała pochtaniajac coraz to nowe ofiary, on sam poczut się odpowiedzialny za swych wiernych. Skierowat swe stowa do mitosiernego Boga, jak pasterz do Pasterza. I Bóg natychmiast sprawit, że chmury pojawity się w oddali. I Bóg utrzymywat chmury $w$ oddali nie pozwalając dotrzeć im na Cypr, dopóki Spirydon ponownie się do Niego nie zwrócit. Gdy święty zapłakat szczerze nad losem swych poddanych z nieba spadt obfity deszcz. I owoce zaczęly dojrzewać, plony rosnać, a wszystkie nieszczęścia skończyły się w jednej i tej samej chwili. A Spirydon - dodaje Metathrastes - otrzymał łaskę większa niż sam Eliasz, jeśli mogę tak butnie stwierdzić.

Był to pierwszy z cudów, które miały stać się udziałem pobożnego biskupa, jeszcze za jego życia.

Jedną z najważniejszych kart w historii Kościoła było zwołanie przez cesarza Konstantego Wielkiego Soboru w Nicei w 325 roku, który później otrzymał również miano „Ekumenicznego". Zwołany on był przeciwko heretyckiej nauce Ariusza, według którego Chrystus nie był prawdziwym Bogiem a zostal stworzony w czasie. Nie uznawał on również współistotności Ojca i Syna a tym samym i Ducha Świętego. Dodatkowo, Syn i Duch przewyższają godnością inne stworzenia: lecz tylko Ojciec zasługuje na miano Boga Doskonałego. Święty Cypryjczyk odegrał na tym soborze jedną z kluczowych ról w obronie ortodoksyjności wiary. Cytowany przez nas już wcześniej Symeon Metathrastes przypisuje świętemu kluczowy udział w stworzeniu tzw. „Credo”/,Wyznania Wiary” (cs. Wieruju), które oddzieliło prawdę od herezji. Do dnia dzisiejszego zachował się opis wystąpienia Spirydona przeciw jednemu ze stronników Ariusza o imieniu Eulogiusz. Oto jego obszerny fragment: Jeden ze świętych ojców z imienia Spirydon, biskup Trimithous, bardzo prosty $w$ naturze $i$ niewykształcony $w$ mowie poprosit o pozwolenie przemówienia do (ariańskiego) filozofa. Lecz ojcowie znając prostote myśli i słów świętego starali się mu przeszkodzić. Ten jednak nie przejmowat się tym, wystapit $z$ tłumu i powiedział: „W imię Jezusa Chrystusa filozofie skup się i wystuchaj co zamierzam powiedzieć". I filozof odpowiedziat: "Mów więc, a ja będę stuchat”. Wtedy Spirydon rzekt: „Jeden jest Bóg, Stworzyciel nieba i ziemi i wszystkich rzeczy pomiędzy nimi. On jest jedynym, Który rządzi czterema siłami niebios. On jest Stworzycielem człowieka z ziemi i to On ustanowit wszystkie rzeczy zarówno te widzialne jak $i$ niewidzialne. Jego odwiecznym Słowem i Duchem niebo i ziemia zostaty stworzone, wielka i cudowna to była praca. A rzeczy następowaly po sobie: gwiazdy, światło, dzień, noc $i$ wszystkie inne rzeczy. To Stowo Boże, Które my znamy 
jest Synem Bożym, zrodzonym z Dziewicy, ukrzyżowanym $i w$ końcu pochowanym. Lecz powstał ponownie, wstapit pomiędzy niebiosa $i$ my wstapimy wraz $z$ Nim $i$ da nam $\dot{z} y c i e$ wieczne. I wierzymy, że przyjdzie ponownie, by osadzić nasze czyny, słowa i myśli. I wierzymy, że jest z jednej natury, wspólnej Ojcu, dzieli z Nim tron i wszelkie honory. Czy się z tym nie zgadzasz filozofie?" Po długiej chwili ciszy mógł on odrzec tylko: "Tak, wydaje mi się, że tak jest”. Aby jeszcze bardziej przekonać wszystkich wątpiących, iż Trójca Święta to Trzy Osoby ale jeden Bóg, Spirydon wziął do ręki kawałek gliny (niektórzy mówią tu o glinianym naczyniu lub cegle) i po uczynieniu nad nią znaku krzyża zawołał: W imię Ojca! Po chwili wybuchł z niej płomień, po czym dodał: I Syna! I natychmiast pociekła woda. Zaś po wypowiedzeniu: I Świętego Ducha! w jego ręku została tylko garstka piasku. Wielu zgromadzonych przecierało oczy ze zdumienia, widząc to niecodzienne zjawisko. Spirydon natomiast chciał $\mathrm{w}$ ten sposób udowodnić, iż tak jak owe trzy elementy: ziemia, woda i ogień, złączone tworzą jedną całość - glinę, to sama analogiczna sytuacja ma miejsce w odwiecznym życiu i relacjach zachodzących między Trzema współistotnymi Osobami Trójcy Świętej: Ojcem, Synem i Duchem Świętym - Trzy Hipostazy, Trzy Osoby ale Jeden Bóg, jedna Boska natura, jedna istota.

Święty Atanazy Wielki w swej „Drugiej Apologii” wspomina, iż Biskup Tremithous wziął udział również w synodzie w Sardyce (dzisiejsza Sofia) (342-343). Świadczy o tym przede wszystkim jego podpis pod synodalnymi postanowieniami.

Święty sprawował Boską Liturgię codziennie. Pewnego dnia, w jej trakcie, kiedy świątynia była pusta a hierarcha wezwał: Pokój wszystkim! (cs. Mir wsiem!), nowicjusz, który był jedynym wiernym obecnym wówczas w cerkwi usłyszał gromki głos Chórów anielskich, który brzmiał: I duchowi twemu! Mogło to oznaczać tylko jedno - nawet niebiosa pomagały Spirydonowi i współuczestniczyły w jego służbie Bogu.

Był on przede wszystkim człowiekiem modlitwy, modlitwy, która nigdy nie gasła w jego ustach i sercu.

Pod koniec swojego życia Spirydon stał się postacią powszechnie rozpoznawaną i darzoną szacunkiem już w całym Cesarstwie. Gdy Konstantyn Wielki podupadł na zdrowiu, jego uzdrowicielem okazał się święty z Cypru. Władca mianowicie, rozpaczliwie wzywał lekarza, obdarzonego mocą Boską, zdolnego go uleczyć. Jeden z historyków zanotował: Bóg ukazał cesarzowi we śnie nieskończona liczbę biskupów i spośród nich tylko dwóch otoczonych było jasna mgła. Konstantyn zinterpretowat te mgłe jako znak, że tylko dwóch $z$ nich ma moc zdolna ukoić jego cierpienia. Lecz Bóg nie ujawnit mu ani ich imion, ani miast $z$ których pochodzili. Listy zostały wysłane w najodleglejsze zakatki państwa przyzywające biskupów przed oblicze władcy. I gdy cesarz nie rozpoznat żadnego z nich posłał po biskupa Cypru Spirydona. Wielki uzdrowiciel przybyt do Antiochii i gdy stanat przed Konstantynem ten od razu go rozpoznał. Cesarz oparł głowę na ramieniu świętego i natychmiast otrzymał oczekiwana pomoc, bo nie było żadnej innej mocy uzdrawiajacej, która przyniosłaby zbawienie od bólu. Żadne lekarstwa, ani inne rzeczy pochodzenia ludzkiego nic nie zdziałały, tylko łaska niebios pomogła.

Nie ulega najmniejszej wątpliwości, iż największymi cudami, które miały miejsce dzięki jego świętym modlitwom były wskrzeszania umarłych. Oprócz historii przywrócenia życia swej zmarłej córce, zachowało się także opowiadanie o pewnej kobiecie, która przyszła do świętego z martwym synem na rękach, prosząc o jego wstawiennictwo. Po krótkiej modlitwie Spirydona dziecko otworzyło natychmiast oczy, zaś matka $z$ wrażenia, radości i szoku, jakiego doświadczyła zemdlała i po chwili zmarła. Święty biskup ponownie wzniósł ręce ku niebu, po czym zwrócił się do owej kobiety: Niewiasto powstań z umarlych i stań na nogi! Tak też się stało.

Na kilka dni przed swoim odejściem do wieczności, Bóg odkrył Spirydonowi w widzeniu, kiedy ma to nastąpić. Tradycja głosi, iż ostatnie jego słowa - choć może przesadnie proste w swej treści ale jakże dobitne - brzmiały następująco: Miłuj Boga i bliźniego. Zasnął w Panu w 348 roku (niektóre źródła podają rok 344 lub 346) w wieku 78 lat. Spoczął w podziemiach świątyni p.w. Świętych Apostołów w Tremithus.

W Cerkwi Prawosławnej jego pamięć obchodzona jest rokrocznie 12 grudnia - czyli w dzień, w którym oddał swą duszę w ręce Władcy życia i śmierci, chociaż i w tej kwestii nie wszyscy są zgodni. Spotkać się można bowiem z opinią, iż Spirydon zmarł nie 12 a 14 grudnia. Tej wersji trzyma się Kościół Rzymskokatolicki, który czci świętego dwa dni później niż prawosławni.

W jaki sposób jednak, imię świętego Spirydona stało się nierozerwalnie złączone z grecką wyspą Korfu, skoro za swego życia nie odwiedził jej ani razu?

\section{Relikwie biskupa Tremithus $i$ ich perypetie}

Po kilkudziesięciu latach od jego śmierci, dokonano wydobycia doczesnych szczątków biskupa. Ku wielkiemu zdziwieniu wszystkich nie dość, że nie uległy one naturalnemu rozkładowi, to wydzielały dodatkowo przyjemną woń. Wewnątrz trumny znaleziono również gałązkę bazylii - roślinę królewską, której nazwa w kulturze greckiej jest terminem, podobnie brzmiącym ze słowem „król” (gr. vasileias - król, vasilikos - bazylia). Kiedy w pierwszej połowie VII wieku, rozpoczęły się najazdy Saracenów na Cypr, w celu uniknięcia zbezczeszczenia i zniszczenia relikwii, zostały one przewiezione przez cesarza Justyniana II do Konstantynopola. Tam miały one przebywać aż do ok. roku 1456, kiedy to kapłan o imieniu Grigorios Polieuktos (niektórzy historycy mówią o ks. Georgiosie Kalochairetisie), w obawie przed ich profanacją ze strony Turków, potajemnie przenosi je na zajmowane wówczas przez łacinników Korfu, które było w jego przekonaniu najbardziej bezpiecznym miejscem. Tam spoczywają one w stanie nienaruszonym do dnia dzisiejszego. Zachowują one naturalną i miękką w dotyku skórę (utrzymującą nieustannie temperaturę, zbliżoną do temperatury ludzkiego ciała, niezależnie od pory roku), całkowite uzębienie i wyraźnie dostrzegalne 
gałki oczne, fakt który potwierdza raz jeszcze, iż dane zawarte w łacińskim Synaksarionie, jakoby święty miał być pozbawiony oka, nie są zgodne z rzeczywistością.

Relikwie spoczywają w relikwiarzu z dwoma zamkami, którą jednocześnie otwiera dwóch kapłanów, posiadających dwa różne klucze. Pobożna tradycja lokalna głosi, iż kiedy istnieją trudności przy jej otwarciu i wieko nie daje się podnieść - oznacza to, iż świętego nie ma akurat „w domu” i zapewne udał się pomagać znajdującym się w trudnym położeniu i pocieszać strapionych. Może o tym świadczyć obuwie, które pokrywa jego święte stopy, a które wykonane z miękkiego materiału, dość często - z powodu widocznego „zużycia” jest wymieniane na nowe. „Stare” buty natomiast, są rozdzielane na części wiernym i stanowią domową relikwię. Tysiące wiernych z całego świata przybywają każdego roku do tego wyjątkowego miejsca, pozostawiając świętemu w podzięce, bądź jako prośby o łaskę, liczne dary, spośród których najczęściej spotykane to złote łampady, umieszczane potem nad relikwiarzem Spirydona. Cztery razy do roku - na pamiątkę szczególnych łask, okazanych mieszkańcom wyspy przez świętego - wynoszone są one ze świątyni i niesione procesyjne ulicami Kerkiry. Są to:

- Niedziela Wejścia Chrystusa do Jerozolimy (Niedziela Palmowa), kiedy wspomina się cudowne ustanie, dziesiątkującej mieszkańców wyspy epidemii dżumy w 1630 roku.

- Wielka Sobota i związane z nią zaprzestanie klęski głodu w 1550 roku.

- Pierwsza niedziela listopada (tzw. Protokiriako), kiedy wierni dziękują świętemu za ponowne wybawienie od dżumy w 1673 roku.

- 11 sierpnia. Tego dnia 1716 roku, Spirydon miał pomóc Kerkireńczykom w zwycięstwie nad Turkami, którzy na ponad miesiąc opanowali ich ojczyste ziemie. W obozie wrogiej armii krążyła wówczas plotka o świętym, który w przebraniu duchownego straszy tureckich żołnierzy, zwiększając w ten sposób panikę przed wenecką flotą i mieszkańcami Kerkiry. Viktorię nad wrogami natychmiast przypisano boskiej interwencji świętego.

Warto w tym miejscu dodać, że relikwie świętego Spirydona, choć zachowane w całości, pozbawione są jego prawej ręki. W XIII wieku, kiedy Krzyżowcy napadli na Konstantynopol została ona odcięta i wywieziona. Nieznane są jej losy przez następne 100 lat. Pewnym jest, iż w 1592 roku została ona przewieziona do Rzymu i wręczona papieżowi Klemensowi VIII. Ten z kolei w 1606 roku przekazuje świętą prawicę kardynałowi Cezaremu Baroniuszowi, który umieszcza ją w klasztornej świątyni Zakonu Oratorianów Santa Maria in Vallicella, o czym zaświadcza wzmianka zachowana w kościelnych archiwach. Potwierdza to także grecki historyk L.S Vrokinis, który powołując się na Christodulosa Vulgarisa pisał, że prawa ręka świętego biskupa znajdowała się w kościele Matki Bożej, gdzie była przechowywana w pozłacanym relikwiarzu - nieznanego autorstwa - w kształcie stożka o wielkości około pół metra, którą zdobi srebrna ikona świętego. Potwierdzić to może tekst pamiętnika jednego $\mathrm{z}$ rosyjskich pielgrzymów, niejakiego
Braskiego, który zachował się do naszych czasów, a który datowany jest na siedemnaste stulecie. Wspomniany pątnik nie omieszkał zanotować $\mathrm{w}$ nim - z niemałym zresztą zdziwieniem - iż podczas pobytu na Korfu i przyłożeniu się do relikwii świętego Spirydona zauważył w nich brak prawej ręki biskupa Cypru, która jak został wówczas poinformowany przez tamtejszego kapłana, znajduje się w Rzymie w świątyni poświęconej Bogurodzicy. A żyjący w tym samym wieku grecki filozof medycyny Nikolaos Vulgaris w liście do łacińskiego biskupa Korfu Karola Labia, doda, że prawe ramię (gr. vracheion) świętego, przechowywane jest w Rzymie z wielką czcią i szacunkiem.

Tam przebywała ona aż do roku 1984. Dzięki wieloletnim staraniom metropolity Kerkiry i Paksosu Tymoteusza i akceptacji ówczesnego papieża - Jana Pawła II, powróciła do Grecji. Od tego czasu ręka ta cały czas zmienia kolor, upodabniając się barwą do pozostałych relikwii i bardzo wolno „pokrywa” się ciałem i to właśnie ona odwiedza dziś różne części Hellady i świata.

Lokalna, pobożna tradycja głosi, iż greckie biskup każdego wieczoru obchodzi wyspę dookoła sprawdzając czy nic jej nie zagraża.

Na Korfu ponad 70\% mieszkańców-mężczyzn nosi to święte imię. Istnieje także wiele rodzin, które z pokolenia na pokolenie nadają każdemu męskiemu potomkowi, właśnie imię „Spirydon”. W samej tylko Grecji jest około 80 cerkwi poświęconych jego pamięci. Wszystko to dowodzi głębokiej, pobożnej czci i uwielbieniu, jakim otaczany jest ten święty. Jego kult jest wciąż obecny na wyspie, a pamięć o nim - z pokolenia na pokolenie - podtrzymywana przez jej mieszkańców z tym większym zapałem, im więcej pielgrzymów przyjeżdża pokłonić się cypryjskiemu biskupowi.

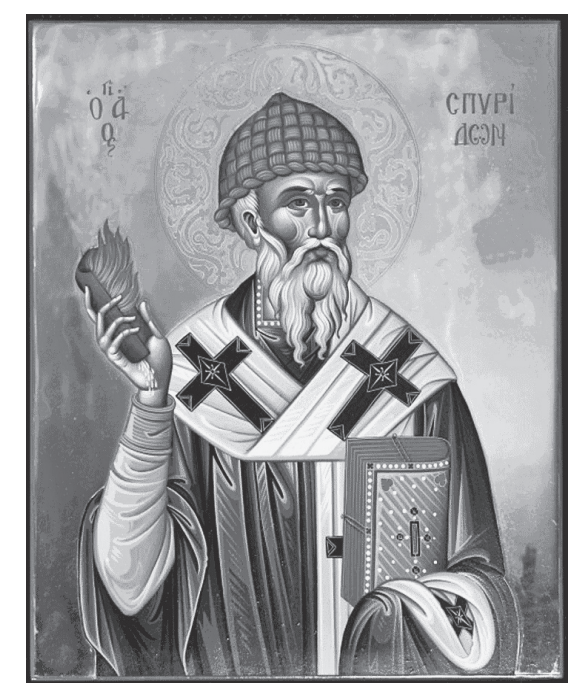

\section{Podsumowanie}

Niezliczone są cuda jakich Spirydon dokonywał i dokonuje do dnia dzisiejszego. Słynie on $\mathrm{z}$ natychmiastowej pomocy, wszystkim zwracającym się do niego ze szczerą prośbą. To wielki orędownik i wybawca od wszelkich 
nieszczęść, niepowodzeń, klęsk i dramatów życiowych. Język ludzki, bardzo często nie jest w stanie wyrazić tego, co przeżywa serce człowieka, który doświadczył - a wielu przypadkach miało to miejsce już niejednokrotnie - jego pomocy. Dlatego warto oddać w takich momentach głos Cerkwi, która opiewając wielkiego hierarchę wzywa nieustannie takimi oto słowami modlitwy: Pierwszego Sobo- ru okazałeś się obrońca i cudotwórca, mający Boga w sercu Spirydonie, ojcze nasz. Przeto zmarła $w$ grobie przywołałeś i żmije $w$ złoto zamieniłeś, i kiedy śpiewałeś święte modlitwy, aniołów wspótsłuzacych tobie miałeś, o świętobliwy. Chwała Temu, Który daje tobie moc, chwała Koronującemu Ciebie, chwała Temu, Który poprzez Ciebie uzdrawia wszystkich (Troparion ku czci świętego Spirydona).

\section{Bibliografia}

Różycki Ł., Żywot Spirydona, [w:] Per aspera ad astra. Materiały z XVI Ogólnopolskiego Zjazdu Historyków Studentów Historia Starożytna, Kraków 2008, s. 169-183.

Wielko A., Święty Spirydon z Tremituntu Cudotwórca, tłum. N. Jakimiuk, wyd. Bratczyk, Hajnówka 2013.

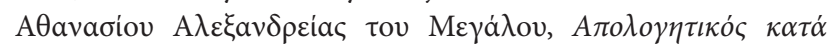

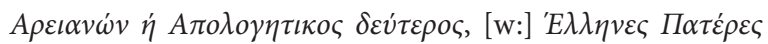

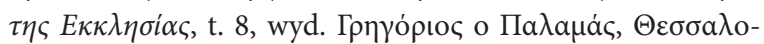
víkך 1973, s. 158.

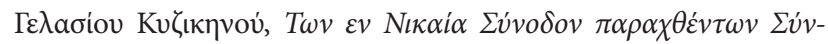

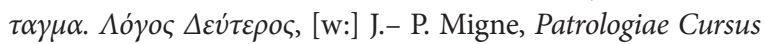
Completus, Series Graeca, t. 85, Paryż 1864, s. 1245-1249.

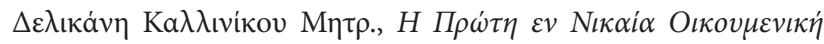

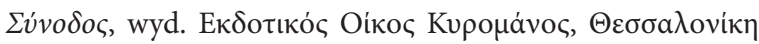
1997.

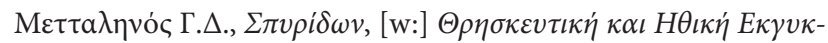

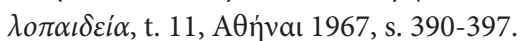

Акафист святителю Спиридону Тримифунтскому, wyd. Bratczyk, Hajnówka 2015, s. 28-32.

http://www.inaa.gr/?p=14980, (dostęp 24.03.2015).

http://www.spyridon-trimifuntsky.narod.ru/zitie_003.html, (dostęp 29.01.2015).

http://www.pigizois.net/kiprioi_agioi/trifilios.htm, (3.03.2015). http://www.pravmir.ru/svyatitel-spiridon-trimifuntskij2/\#ixzz3PwlXSwsL, (dostęp 29.01.2015).

http://www.saint.gr/3247/saint.aspx, (dostęp 29.01.2015).

http://www.kerkyrainfo.gr/nomoskerkyras/agiosspyridonas/, (dostęp 29.01.2015).

http://www.imcorfu.gr/agios\%20spiridon.htm, (dostęp 29.01.2015). http://simvol-veri.ru/xp/gde-jivet-svyatitel-spiridon.html, (dostęp 6.03.2015).

https://antexoume.wordpress.com/2013/12/12/o-áyı૬-

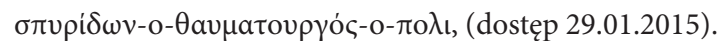

http://users.uoa.gr/ nektar/arts/tributes/fwths_kontogloy/o_ agios_spyridwn.htm, (dostęp 29.01.2015).

http://myronzwhs.gr/biosagioyspyridwnos.html, (dostęp 29.01 . 2015).

http://cerkiew.info/pl/biblioteka/artykuly/f/2/258,0, (dostęp 29.01 . 2015).

http://www.cerkiew.pl/index.php?id=261\&tx_ttnews\%5Bpointer\%5D=1\&tx_ttnews\%5Btt_news\%5D=21826\&tx_ttnews $\% 5$ BbackPid $\% 5 \mathrm{D}=3 \& \mathrm{cHash}=3 \mathrm{~b} 5698358 \mathrm{e} 3 \mathrm{a} 92 \mathrm{~d} 27 \mathrm{fca}-$ 754e954b64a2, (dostęp 6.03.2015).

http://www.apologitis.com/gr/ancient/agios_Spyridon_k.htm, (dostęp 20.03.2015).

http://biblia-swieci.pl/spirydion.html, (dostęp 19.03.2015). 
ISSN 1508-7719

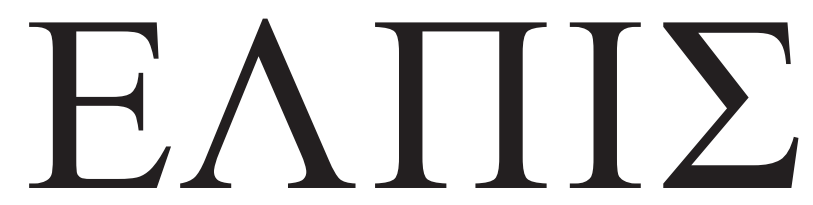

CZASOPISMO TEOLOGICZNE KATEDRY TEOLOGII PRAWOSŁAWNEJ UNIWERSYTETU W BIAŁYMSTOKU

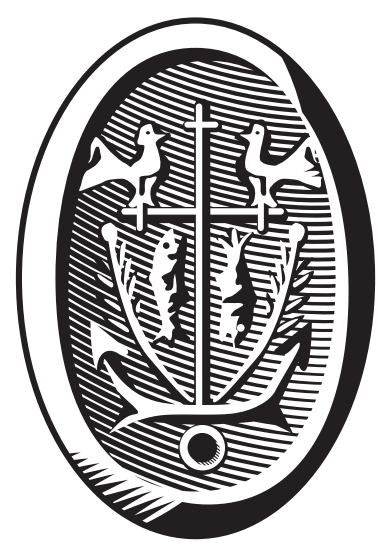

ADRES REDAKCJI

15-097 Białystok, ul. M. Skłodowskiej-Curie 14 tel. 85 745-77-80, e-mail: redakcja@elpis.edu.pl www.elpis.uwb.edu.pl 